\title{
CONTRA O ABYSMO DA IGNORÂNCIA: O BAPTISMO DA INSTRUÇÃO! LIBERDADE DE ENSINO E OBRIGATORIEDADE NO SÉCULO XIX E INÍCIO DO XX
}

\author{
Aline de Morais Limeira ${ }^{1}$ \\ Cíntia Borges de Almeida ${ }^{2}$
}

\section{RESUMO}

No século XIX a instituição escolar foi forjada e legitimada pelo poder público e pela sociedade como o espaço privilegiado e mais adequado, para se promover as luzes da instrução. Diversos tipos de escolas e práticas educativas surgiram a partir de iniciativas de particulares e pelas ações do Estado Imperial em todo país - ou mesmo pela associação de forças entre as esferas pública e privada, como nos deram a ver os processos de subvenção. Neste sentido, consideramos ser imprescindível para o campo da História da Educação compreender melhor a organização daquelas experiências para esquadrinhar os problemas da educação no nosso próprio tempo. Contribuindo com a tarefa, este estudo apresentou e refletiu acerca de alguns aspectos relacionados ao tema, a partir da análise de ordenamentos legais: liberdade de ensino, obrigatoriedade e fiscalização. Princípios que estiveram presentes nos termos da lei e nos posicionamentos de intelectuais e dirigentes do poder público como tema de inúmeros debates. A realização do investimento foi possível a partir de uma operação metodológica que se baseia na leitura e apreciação de fontes primárias datadas dos séculos XIX e XX: ofícios, relatórios, legislações, jornais e propagandas.

Palavras-chave: História da Educação; Instrução; Subvenção; Liberdade de Ensino; Obrigatoriedade.

\section{AGAINST THE ABYSS IGNORANCE: THE BAPTISM OF INSTRUCTION! FREE EDUCATION AND COMPULSORY IN THE 19TH AND BEGINNING OF 20TH CENTURIES}

\begin{abstract}
In the nineteenth century the school institution was forged and legitimized by government and society as privileged, as appropriate, to promote the lights of instruction. Several types of schools and educational practices emerged from initiatives by individuals and by the actions of the Imperial State across the country - or even a combination of forces between the public and private spheres, as we got to see the processes of grant. In this sense, we consider it essential to the field of History of Education better understand the organization of those experiences to scrutinize the problems of education in our own time. Contributing to the task, this study presented and reflected on some aspects related to the topic, from the analysis of legal jurisdictions: freedom of education, compulsory and supervision of education. Principles that were present under the law and the placements of intellectuals and leaders of public power as the subject of numerous debates. The realization of the investment was made possible from a methodological operation that relies on reading and assessment of primary sources dating from the nineteenth and twentieth centuries: crafts, reporting, laws, newspapers and advertisements.

Key-words: History of Education, Instruction, Grant, Freedom of education, compulsory education.
\end{abstract}




\section{Introdução}

No século XIX, projetos de instrução inscreviam-se como estratégias nos debates atinentes à construção de uma ideia de nação e do próprio Estado Imperial. A partir do investimento nas luzes do saber, o Estado, de população heterogênea, com imensidão territorial e experiências culturais mistas, poderia alcançar desejadas condições de governo. Tornava-se necessário montar um aparato jurídico, político e institucional de sustentação de suas funções.

A escola, como um dispositivo, constituiu-se a partir de um conjunto variado de iniciativas a partir do qual se estabelecia quem deveria frequentá-la, quem deveria ensinar, como deveriam ensinar, e o que deveria ser aprendido. Institucionalmente, vai sendo delineada na medida em que ocupava lugar privilegiado naquele processo, sendo vista como o investimento adequado para que o empreendimento alcançasse êxito: instruir para o progresso. Seu acesso ficou estabelecido como gratuito após a Independência com a promulgação da Constituição de 1824, que garantiu a gratuidade do ensino primário para todos os cidadãos brasileiros - um princípio constitucional regulamentado em 1827, com a primeira Lei Geral de Ensino e a consequente criação das "escolas de primeiras letras".

Tomada, portanto, como uma máquina social e politicamente estratégica a escola passou aos poucos a se tornar também obrigatória em diversas províncias do Brasil, ainda no século XIX. Ao legitimá-la, o dispositivo da obrigatoriedade funcionaria como estratégia e produziria positividades, ou seja, seu caráter compulsório tratava de atingir e gerir a população dos pequenos, de modo a equipá-la com os códigos mínimos do mundo civilizado, e com os efeitos disciplinares correlatos.

A premissa da obrigatoriedade do ensino, como uma medida de governo, inserida num processo civilizatório e num projeto educacional pensado para o progresso da nação, com o objetivo de garantir a expansão da instrução elementar, foi defendida pelos países considerados "mais avançados". Seu debate ganhou relevância pela justificativa de que "os países que a adotavam na instrução elementar tinham conseguido difundir completamente a escolaridade entre a população" (WERLE, 2008, p. 176), garantindo o desenvolvimento e o progresso de suas nações. Esta realidade internacional aparece, então, como espécie de premissa para um silogismo que conclui que obrigatoriedade da educação é condição sine qua non para o desenvolvimento nacional, exercendo, com isso, uma força de legitimação e persuasão, como parte integrante dos princípios democráticos. Assim, este foi um dos mais fortes argumentos defendidos para efetivar essa política educacional, pois países, "os mais livres, como a Suíça, a Inglaterra, a Bélgica, Holanda e na América os Estados Unidos" (idem, p.176), não deixando de citar o possível pioneirismo da Prússia, adotaram o ensino obrigatório no interesse dos próprios Estados e dos cidadãos.

Minas Gerais discutiu este dispositivo de forma pioneira no país a partir a lei n.13 de 1835. Seu Artigo 12 dizia:

Os pais de família serão obrigados a dar a seus filhos a instrucção primaria do $1^{\circ}$ grau ou nas escolas publicas, ou particulares, ou em suas próprias casas, e não os poderão tirar delas enquanto não souberem as matérias do mesmo grau (LEI n.13, 20/03/1835).

No Mato Grosso, a implementação desta norma aconteceu em 1837. No Rio de Janeiro aconteceu depois, em $1854^{3}$. Tornou-se obrigatória a frequência escolar para meninos e meninas, livres e vacinados, entre sete e quatorze anos de idade nos níveis de $1^{\mathrm{o}}$ grau ou $1^{\mathrm{a}}$ classe (sob pena de multas de 20 a 100 Réis, cobrada dos pais ou responsáveis). O ensino 
secundário, no entanto, não foi considerado obrigatório e, consequentemente, continuaria restrito a uma pequena parcela da população livre ${ }^{4}$. Como a obrigatoriedade do ensino foi uma das medidas atribuídas como responsabilidade das províncias, as experiências são muito diversas - a província de Rio Grande do Sul, por exemplo, decretou esta lei em 1871.

O Conselheiro de Estado João Alfredo ${ }^{5}$ via a obrigatoriedade como "instrumento possibilitador" da expansão do ensino e com ela, a conquista dos ideais civilizatórios. Logo, em seus discursos, mais que elementos que comprovassem um pensamento voltado para as questões de direito e cidadania, pode-se inferir que seu interesse estava ligado às políticas de controle social que faziam parte das medidas para se alcançar o progresso. Retirar da ignorância, disciplinar e instruir dentro dos preceitos de governo era um dos elementos para se estabelecer determinada ordem. Nesse caso, a participação do Estado, tanto para oferecer a educação quanto em conduzi-la, era ponto crucial para o alcance do referido controle.

Ampliando o debate, nos seus pareceres de 1882 e 1883, Rui Barbosa atribuiu à obrigatoriedade um papel estratégico no processo civilizatório, pois a grande maioria da população brasileira era analfabeta, o que tornava indispensável a compulsoriedade do ensino. A instrução primária precisava ser expandida. Para isso, juntamente com a obrigatoriedade, ele argumentou em favor da liberdade do ensino, afirmando que esta medida "alavancaria a expansão da instrução primária".

Do mesmo modo, como a instrução seria um remédio para os males da população (combatendo a ignorância, a marginalidade, criminalidade, falta de hábitos e moral, os vícios), a formação de cidadãos úteis serviria de utilidade para a sociedade. Sua preocupação não era com o indivíduo, mas sim com a transformação social para o projeto de nação civilizada (BARBOSA, 1947).

Durante a segunda metade do Império e nas primeiras décadas republicanas foram constantes os debates em torno da necessidade de tornar o ensino primário compulsório. As legislações que implementaram a obrigatoriedade do ensino também se fizeram presentes, embora seja necessário enfatizar que o estabelecimento dessas leis não conseguiu evitar que entraves dificultassem o cumprimento da norma. Havia um afastamento daquilo que era imposto pela lei e sua aplicabilidade. Ainda assim, esses documentos são importantes por representarem o que estava sendo discutido naquele tempo, ainda que não efetivamente aplicado. As leis que regulamentam as políticas de ensino representam importantes fontes oficiais, elaboradas por órgãos públicos de governo, e devem ser percebidas como significativos artefatos para a reconstrução da História da Educação (BORGES, 1998).

Estas medidas foram debatidas e esbarraram em muitos conflitos de opiniões. Alguns alegavam que famílias pobres obtinham pelo trabalho das crianças uma suplementação de salário que lhes era indispensável e, por isso, a permanência da criança na escola não seria possível. Mas, acreditava-se que a escolarização era uma alternativa necessária para o progresso da nação e para a inserção desses cidadãos na sociedade. Para garantir o cumprimento dos direitos do indivíduo e para atender aos interesses de governo, a escola e a frequência obrigatória atuariam como importante instrumento de gestão do "múltiplo".

Com a necessidade de se fazer cumprir a presença do aluno na escola e ao mesmo tempo, não privar o indivíduo de frequentar o trabalho, era preciso a adoção de uma medida que conciliasse escola e trabalho. Neste caso, como as soluções são forjadas a partir da invenção dos problemas, escolas noturnas foram criadas para atender justamente o aluno que precisava trabalhar durante o dia, sem descumprir a obrigatoriedade de sua instrução. 
Desta feita, diante de uma necessidade urdida, de uma solução proposta para combater o atraso do país, o Estado Imperial lançou mão de mecanismos para tornar crível a tarefa de promover a instrução. A instituição escolar, tornada gratuita e de frequência obrigatória, pensada para amparar no seu espaço o futuro do país deveria ser distribuída por todo o território. Já que o fardo era caro e pesado, pareceria mais oportuno dividi-lo. Foi então que se declararam liberadas as práticas de ensino, o que serviu como incentivo à iniciativa particular.

Tratou-se de prescrever uma liberdade sem restrições que foi garantida pelo poder público em legislação, desde a Constituição do Império de 1824. Nela, ao contemplar, genericamente, a questão da atividade privada estava declarada livre qualquer gênero de trabalho, indústria ou comércio.

\section{Liberdade e obrigatoriedade do ensino: dispositivos para fortalecer o projeto de escolarização}

No decorrer do século XIX, as propostas de ensino defendidas no âmbito do Ministério do Império, por conservadores e liberais alternados no poder, apresentaram-se diferentes em muitos aspectos. Porém, havia também algumas semelhanças e alguns pontos básicos nos quais os dirigentes tendiam a concordar. Um deles referia-se justamente a este princípio de liberdade.

Naquela ambiência apareceu uma diversidade de formas de organização escolar e heterogêneas experiências e práticas docentes. Emergiram várias iniciativas para instruir a população livre, pobre, negra, trabalhadora, escrava, com deficiência física nos limites de uma educação formal ou informal, oferecida por estabelecimentos públicos, religiosos, militares, particulares, subvencionados. Como exemplo, segue:

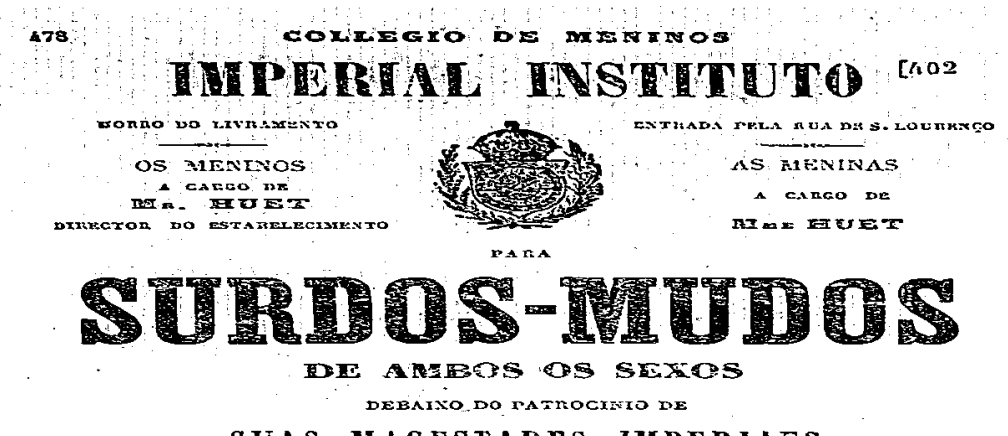

SUAS UAEESTADES IMPERIAESP

(Almanak Laemmert, 1859, p.476)

Neste sentido, a escola foi adquirindo especificidade, e o princípio da escolarização sendo, paulatinamente, capilarizado. A adesão à forma escolar moderna foi feita por forças distintas. Atuando na formalidade ou informalidade, muitos se empenharam na empreitada, tornando-se os principais responsáveis pela emergência dos equipamentos escolares e por uma vasta série de iniciativas de caráter educativo. Ora somavam suas forças, como aliados, ora confrontavam-nas, em campos distintos. Daí resulta não poderem ser vistos como forças isoladas ou completamente separadas: as ações que promovem se encontram 
articuladas, embora nem sempre na mesma direção, com a mesma intensidade e valendo-se dos mesmos recursos. Estas forças são: (o Estado Imperial [em construção], as manifestações religiosas [católicos, protestantes, espíritas, indígenas, orientais do mundo árabe, afro-brasileiros], e a Sociedade Civil [agremiações, grupos, associações, sociedades, clubes], etc.) (GONDRA \& SCHUELER, 2008).

Propagando a necessidade de disseminação das luzes da instrução, o poder público deparava-se com a expansão significativa de iniciativas criadas e mantidas por particulares. Para diferentes autoridades daquele tempo, a importância atribuída ao ensino elementar manifestava-se pelo grande impulso que foi dado no sentido de criar escolas. Assim, concomitante à efervescência dos debates acerca do processo de escolarização, se via um crescimento significativo de experiências, como evidencia o exemplo:

Instrução Gratuita. Collegio do Mosteiro de São Bento. A matricula para as aulas primarias começam no dia 7 de janeiro e as aulas abrem-se no dia 11. A matricula para as aulas secundarias começa no dia 18 e as aulas abrem-se no dia 3 de fevereiro - Frei Bento da Trindade Cortez $(O$ APÓSTOLO, 1886, p.4).

De um modo geral, a política pública de difusão do ensino elementar, ganhou um adepto de maior relevo que o próprio Estado Imperial. Nos termos quantitativos do processo em questão, à iniciativa particular coube uma difusão mais significativa do ensino primário (e secundário) que o poder público. Portanto, a escolarização não se configurava naquele tempo como um projeto imposto pelo Estado, ou de interesse exclusivo seu, mas, apropriado, reapropriado, defendido ou combatido pela sociedade (LIMEIRA, 2010). É o que foi percebido na Corte.

Em contrapartida, segundo se pode observar no caso de Minas Gerais, até a década de 1860, o discurso predominante consistia em reforçar a ideia de que a instrução deveria ser oferecida pelo Estado, já que o mesmo consistia o principal responsável pelo cumprimento da fiscalização. Segundo tais discursos, o problema com a falta de fiscalização tornava-se uma questão grave e, somente com o ensino sob "os olhos do Estado" seria possível controlar o processo civilizatório da população.

Os relatórios dos presidentes da província/estado de Minas, de seus inspetores e de seus diretores da instrução eram enfáticos ao dizer que, apesar das leis trazerem as normas e as regulamentações que deveriam ser adotadas pelas escolas particulares e pelo ensino domiciliar e/ou particular em geral, não era possível precisar os números referentes a esse ensino, por falta de informação dos professores, pela inexatidão dos recenseamentos, pela falta de fiscalização da instrução particular, "das quaes não tem sido possível obter notícias exactas e circunstanciadas" (VEIGA, 1840, p.XXXV) ${ }^{6}$, de onde não "há cálculo dos que frequentão nos mappas do Directores" (PENNA, 1856, p.4) ${ }^{7}$, de onde "necessita reportar à probabilidade apresentada nos anteriores relatórios" (VASCONCELLOS, 1854, p.1) . $^{8}$

Ainda que o controle do Estado se mantivesse, observamos que o discurso sofreu alteração nas últimas décadas do período imperial. De acordo com os discursos parlamentares ${ }^{9}$, tratava-se de um período que a maioria dos professores primários mineiros não era formada pelas escolas normais, período no qual o sistema de inspetoria era falho e passível de burlas, que os próprios professores "falsificavam" os dados nos mapas de frequência para obter gratificações ou para não ter suas escolas fechadas por falta de matrículas ou frequência ${ }^{10}$, etc. Ainda assim, observamos uma alteração nos discursos mineiros a partir da lei n. 1.618 de 02 de novembro de 1869 , em relação à instrução fora das escolas públicas. Antes da nova norma o ensino particular, em qualquer lugar da 
província, só era permitido nos lugares que não havia escola pública. Com a medida legislativa de 1869, tornava-se possível abrir uma escola sem necessidade de licença e nem de prova de capacidade intelectual ou moral dos professores, havendo apenas obrigações sobre leis vigentes e dados estatísticos. Vejam que a formação não era o mais importante e sim, os números, matrícula e frequência. Ou seja, estamos analisando um longo período que abarca o século XIX e início do XX onde o Estado ainda não conseguia ter controle sobre as escolas públicas, ainda que este controle fizesse parte de seu interesse.

Logo, é interessante observar indícios de uma nova necessidade da época e/ou novo interesse social, em relação ao controle da instrução pelos poderes públicos, pois, no Império havia uma preocupação intensa em controlar o ensino, já em suas últimas décadas como no início do século XX, a liberdade do ensino e a "transferência da responsabilidade pela educação" ganharam espaço nos discursos proferidos.

No diagnóstico destas experiências, muitas proposições de regulamentações foram sugeridas no Brasil inteiro. Na Reforma da Corte, capital do Império, em meados do Oitocentos (1854), decretada pelo conservador Couto Ferraz, viu-se que este princípio da liberdade era garantido, embora com muitas restrições (pedido de licença para criar colégios ou ensinar particularmente, exigência de habilitação). $\mathrm{O}$ discurso reformista apoiava a expansão da iniciativa particular, mas a submetia ao controle e à fiscalização do Estado Imperial. O Artigo 111, cuja determinação é precisa e generalizante, traduz este plano para o ensino primário e secundário. Nele, se observa que "As escolas particulares ficam sujeitas á inspecção dos Conselhos Municipaes e Inspectores Parochiaes. Os inspectores representarão ao inspector geral sobre qualquer facto que possa desconceituar o collégio ou o professor" (Artigo 112).

Nos anos seguintes, a liberdade de ensino acompanhava também as medidas gerais da política do Ministro Leôncio de Carvalho ${ }^{11}$. No Decreto de 1879, de sua autoria, afirmava-se livre o ensino nos níveis primário e secundário na Corte Imperial e superior em todo o Império. E sua prescrição ultrapassava o termo de criação de colégios, estendiase à educação livre do controle estatal para adoção de métodos e programas de ensino, para frequência dos discentes nos estabelecimentos públicos ou particulares, para manifestação de crenças e doutrinas professadas por diretores ou professores, etc. (MARTINEZ, 1999).

No que se refere às concepções sobre os limites de ação do Estado no campo da educação é possível perceber que havia divergências. De acordo com o legislador da década de 1870, Leôncio de Carvalho, a liberdade de ensino era uma prática defendida desde as primeiras décadas imperiais, embora não fosse um consenso. Acreditava-se que esta medida auxiliaria no processo de expansão do ensino, podendo implicar igualmente em economia para os cofres públicos.

O fato é que este pressuposto (liberdade de ensino, incentivo ao comércio particular da educação) foi objeto de profundas críticas ou de acentuadas defesas na época. A medida garantida em lei era também defendida por intelectuais, profissionais da educação, políticos. Para o Ministro Liberato Barroso,

ao lado do ensino primário gratuito e obrigatório deve marchar e se desenvolver o ensino livre [...] Limitar a esphera do ensino privado, quando o ensino oficial não satisfaz a todas as necessidades, é prescrever a ignorância [...] O estado deve exercer uma inspeção salutar sobre a liberdade de ensino, mas, não crear-lhe embaraços e dificuldades [...] traz economia para o Estado ${ }^{12}$.

Nas considerações do político contemporâneo Antônio Almeida de Oliveira, “o ensino particular não era só poderoso corretivo para o ensino público, era uma fonte de Revista HISTEDBR On-line, Campinas, $n^{\circ}$ 52, p. 90-106, set2013-ISSN: 1676-2584 95 
economia para o estado, uma das maiores conquistas da civilização moderna" (OLIVEIRA, 2003, p. 89). Por este motivo, "a liberdade introduzida no Estado expõe censuras porque naturalmente ousa o que o Estado não pode fazer. O Estado governando o ensino privado e tirando-lhe a liberdade necessariamente o aniquila" (Idem, p.90). E acrescenta:

\begin{abstract}
Nos tempos coloniais o ensino era completamente livre. Todo aquele que quisesse podia sem necessidade de licença criar aulas de primeiras letras, colégios e quaisquer outros estabelecimentos científicos ou literários. Usamos tanto que por ocasião da nossa independência notou-se que, para uma colônia, a instrução primária estava bastante derramada, assim como que, para isso, muito concorria o ensino particular por ser então limitado o número das escolas públicas. Feita a independência o ensino particular não podia deixar de ser respeitado. A constituição portanto nada dispôs que pudesse tolhe-lo antes com seu silêncio sancionou a prática até então estabelecida. Ainda por ocasião da Lei Geral de 15 de Outubro de 1827 nenhuma restrição quis o legislador fazer a liberdade de ensino particular. Veio após o Código Criminal e as coisas permaneceram no mesmo estado. Finalmente em 1834 a Reforma Constitucional descentralizando o serviço de instrução pública nenhum preceito consagrou que de lugar a supor-se suprimida a liberdade de ensino. O Brasil, portanto, que sempre tinha gozado da liberdade de ensino, não podia deixar de ser privado dela (OLIVEIRA, 2003, p. 94).
\end{abstract}

Nos Relatórios dos Ministros do Império de 1871, havia também considerações interessantes que expressam os debates contemporâneos. Discursando sobre a Instrução primária particular, o Ministro José Bento da Cunha Figueiredo registra:

E pois, é evidente que a instrucção particular prepara avultado numero de cidadãos e que manda a prudência animar tão valiosa coadjuvação [...] Limitar-me-ei a ponderar a conveniência de não obstar, com demasiada exigências, o livre desenvolvimento do ensino, importando pouco a idade, uma vez que os indivíduos que pretendem abrir escolas próvem sua moralidade: a vigilância activa do inspector do districtor e dos pais mais illustrados fiscalizará sufficientemente a capacidade profissional. Longe de embaraçar a abertura de escolas particulares (FIGUEIREDO, 1871, p. 20)

Outros discursos que estavam em consonância com a defesa que se leu acima contribuem para dimensionar o debate em questão. José Ricardo Pires de Almeida era médico da Inspetoria Geral da Higiene, e publicou uma obra sobre Instrução no ano de 1889: L'Instruction Publique au Brésil - Histoire et Legislation. Para ele, a iniciativa privada prospera, ainda que fossem cobrados altos preços pela instrução que oferta:

Se se pudesse, como na Inglaterra, contar com o espírito de iniciativa ou com a associação particular ter-se-ia alguma esperança no futuro. Mas, está longe de ser assim [...]. Os estabelecimentos privados de instrução primaria e secundária continuaram a prosperar, e a maior parte deles oferecia aos pais de famílias suficientes garantias em relação a instrução. (ALMEIDA, 2000, p. 110). 
A defesa do ensino livre também fez parte do pensamento político defendido por Tavares Bastos em "A província: estudo sobre a descentralização no Brasil" (1870). Fazendo circular ideias "libertárias" do século XVIII, ele viu na descentralização política, assim como na liberdade do ensino, medidas democráticas indispensáveis para se organizar uma sociedade moderna. Bastos (1996), via na centralização política um descompasso entre os interesses do Estado e do indivíduo.

Sobre a alegação que o Estado brasileiro nada fazia a favor da instrução do povo, Bastos considerou:

Seja livre o ensino: não há mais abominável fórma de despotismo do que o de governos nullos que, sem cooperarem seriamente para o progresso das luzes, embaraçam os cidadãos que emprehendem esta obra evangélica, e ousam sujeitar ao anachronico regimen das licenças e patentes a mais nobre das artes, aquella que lavora com o espírito (BASTOS,1996, p.232).

Suas ressalvas eram atinentes à ideia de que num país "atrasado" como o Brasil, onde o povo não queria e/ou não podia prover por si mesmo a criação de boas instituições de educação, ainda se fazia necessário que o Estado tomasse para si essa tarefa, proferindo dos males o menor. Da mesma forma como o povo não era capaz de conduzir essa tarefa, a sua ignorância negligenciava sua busca pela instrução. Assim, não se podia deixar de ser obrigatório o ensino onde existisse escola. Logo, observamos que Bastos entendia que o Estado não podia desempenhar a sua tarefa sem o auxílio moral das populações, ao defender os direitos do indivíduo e a extensão da liberdade. Mas, ele também entendia que, devido às circunstâncias de atraso da civilização brasileira, que as populações não podiam dispensar a sua condução pelo Estado em outras circunstâncias, a exemplo: a instrução do povo. Para isso, o Estado devia abrir escolas em números "suficientes" para que não fosse preciso penalizar parte da população que não negligenciava a educação, mas que estava sofrendo dos males da nulidade dos governos em se tratando da instrução.

Bastos ainda analisou a instrução sob o olhar das despesas orçamentárias com esse serviço. Diferente do que vimos no discurso de Leôncio de Carvalho, que defendia uma economia nos cofres públicos, o deputado alagoano afirmou:

Todos os esforços no sentido de combater a ignorância e a rudeza do povo, estacam diante da questão financeira; porquanto é preciso convir nisto: não há systema de instrucção efficaz sem dispêndio de muito dinheiro (Idem, 1996, p.238).

Apesar de não colocar em dúvida a defesa de alguns destes homens públicos "pela luta da liberdade contra a força, do indivíduo contra o Estado" uma coisa é certa: a preocupação com a sociedade e com o espaço urbano após a abolição da escravidão. Ainda que fizesse parte do seu discurso a emancipação do escravo, por exemplo, Tavares Bastos se preocupava com os efeitos dessa ação. Para onde iriam? Quem sustentaria o processo produtivo? Como combater a ociosidade, ignorância e marginalidade?

$\mathrm{Na}$ conjectura de suas observações, notamos que, assim como a população das classes "subalternas" necessitava se instruir para requerer seus direitos e não mais, apenas atenderem aos interesses do Estado, a nova população emancipada deveria também se capacitar: 
Comprehendam governo e povo que não há mais urgente reforma: a emancipação do escravo o exige, porquanto Ella há de prosseguir a sua marcha fatal por entr dous perigos, o instincto da ociosidade e o abysmo da ignorância. Diminui o segundo; tereis combatido effizcamente o primeiro[...]. O que haveis de offerecer a esses entes degradados que vão surgir da senzala para a liberdade? O baptismo da instrução. O que reservareis para suster as forças productoras esmorecidas pela emancipação? O ensino, esse agente invisível, que, centuplicando a energia do braço humano, é sem duvida a mais poderosa das machina de trabalho (BASTOS, 1996, p.254).

Estes elementos que compunham o processo de escolarização no século XIX, em várias províncias do Brasil, também constituíram temas de debates no século XX. Vestígios que evidenciam tal observação podem ser percebidos com notícias divulgadas nos jornais de Juiz de Fora acerca das leis republicanas (ALMEIDA, 2012, p.181). O Correio de Minas destacou o ofício enviado por Carvalho Britto a todos os inspetores técnicos de instrução pedindo-lhes que procedessem ao levantamento estatístico do ensino particular em cada circunscrição. Estava no plano do governo:

[...] estimular o ensino particular que, para honra do Estado, por ahi se exerce de modo considerável; e, consagrando essas idéias, o regulamento de instrução pública em vigor estabelece no capítulo II que o Estado estimulará e auxiliará o ensino primário realizado em domicílio particular por iniciativa das famílias, e indicou a maneira de se realizar a assistência pública nesta matéria (CORREIO DE MINAS, 13/08/1907, grifos nossos).

Considerando tais posicionamentos, tornam-se mais que pertinentes as palavras do historiador francês Jean Marie Goulemot: "a construção do estado em suas formas modernas não só permitia a delimitação do que doravante já não pertencia ao público, como ainda ofereceu garantia de proteção ao privado" (GOULEMOT, 1991, p.232). E a proteção à instância privada não se resumia aos discursos favoráveis ou às legislações que lhe garantiam o direito de liberdade de ensino.

Um dos instrumentos de promoção do comércio particular no campo da instrução oitocentista referia-se aos processos de subvenção. A partir deles, era o Estado Imperial quem garantia financeiramente o atendimento de meninos e meninas pobres (somente?) nos colégios particulares ou sociedades filantrópicas, mediante o pagamento de suas mensalidades ou concessão de espaços, doação de materiais, livros, compêndios, vestuário etc. Isso permite compreender, inclusive, que não foi apenas no âmbito dos poderes públicos que a instrução foi discutida. Diversos setores da sociedade, reunidos em agremiações, sociedades e associações (leigas ou religiosas) defenderam a causa da instrução como um problema social.

O impulso à atuação dos particulares fazia parte da política geral de Instrução Pública, a partir de diversas formas de incentivo e contribuição. Seja envio de materiais para o ensino, doação de compêndios, pagamentos de subvenções ou mesmo financiamento de uniformes para alunos pobres de instituições particulares, como mostra um ofício datado de novembro de 1873 (Arquivo Geral da Cidade do Rio de Janeiro). Nele, a Inspetoria Geral da Instrução Primária do Município da Corte pede ao Ministro do Império para que seja entregue ao delegado da freguesia da Lagoa, a quantia de 500\$000 mil Réis, que garantiria o fornecimento de vestuário "decente e simples" para os alunos pobres que frequentavam o Collegio da Irmandade Nossa Senhora da Conceição. 
Somada a estas experiências, é possível também identificar as iniciativas (formais e documentadas) de subvenção aos colégios primários particulares da Corte Imperial, a partir da leitura e análise dos documentos manuscritos (AGCRJ). São procedimentos a partir dos quais o Estado Imperial concedia auxílios financeiros a professores e colégios particulares, no intuito de subsidiar o ensino primário gratuito a meninos e meninas pobres, moradores de localidades em que se encontram distantes as escolas públicas (LIMEIRA, 2010).

Entre aqueles documentos analisados, o que evidencia a menor datação refere-se à segunda metade da década de 1850. Ou seja, os primeiros registros acerca das práticas formais de subvenção pública a estabelecimentos particulares encontrados na investigação, datam de período posterior ao decreto que estabelece o Regulamento de 1854, segundo o qual (Artigo 57) os menores de 12 anos, encontrados "vagando pelas ruas da Corte", em estado de pobreza ou "indigência", deveriam ser matriculados nas escolas públicas ou particulares subvencionadas pelo Estado. O Artigo 115, outro que também faz menção a estes procedimentos, registrava que, ao lado dos colégios, professores que mantinham aulas particulares também poderiam ser beneficiados com esta prática.

No decorrer de 1880, até o final do Império brasileiro, as subvenções continuaram sendo concedidas aqueles colégios privados da Corte Imperial e do Brasil (Em Minas, apontou-se 108 Colégios particulares. De acordo com os registros apontados por José Ricardo Pires de Almeida havia 457 colégios particulares [ensino primário] subvencionados pelo Tesouro Nacional em todo o país, no ano de 1888) (LIMEIRA, 2010, p.229). No entanto, a informação da existência de "108 colégios particulares" diverge dos relatórios dos presidentes de Minas Gerais. A partir do final do Império, a estatística da instrução ocupava cada vez mais espaço nos discursos das figuras públicas interessadas na área educacional, "no entanto as ações com vistas à organização dos levantamentos quantitativos eram pouco ou nada profícuas" (GIL, 2008, p.487). Naquele momento, ainda segundo a autora, "não se mencionava a inerente relatividade dos dados estatísticos" (GIL, 2004, p.2).

Nesse sentido, devemos entender esse tipo de documento afastado da atribuição de "imagem da realidade". Assim, menos do que "revelar a realidade", as estatísticas constroem os "fatos" e criam os modos de ver. Os números respondem a escolhas que não são nem completamente conscientes nem tão arbitrárias, mas que definem o ângulo de visão que é sempre necessariamente parcial. Essas escolhas, por sua vez, ligam-se aos objetivos que motivaram a busca da informação quantitativa (GIL, 2004, p.3).

Os dados que estes vestígios - resultado da correlação de fontes (relatórios ministeriais, mapas de escolas e colégios, anúncios, ofícios) - nos apresentam, inobstante a fragilidade dos mesmos, são modestos, mas interessantes, pois dão conta de evidenciar aspectos atinentes ao público que frequentou aquelas escolas. O que os pesquisadores da História da Educação afirmam é que havia prioridade para a escolarização da população urbana, e isso se vê por conta de uma distribuição desigual das escolas públicas entre as áreas centrais e periféricas da cidade (LIMEIRA, 2010). Mas isso não significa afirmar que somente os meninos e meninas residentes das áreas urbanizadas da Corte Imperial receberam Instrução Pública ou particular, e menos ainda que somente os filhos das famílias abastadas e brancas puderam aprender a ler, escrever e contar nos colégios, ou com mestres particulares.

\section{Instrução para quem e por quem?}


Havia grande diversidade de meninos e meninas que frequentavam aqueles estabelecimentos, e não somente os filhos brancos das famílias ricas da cidade, seja porque era bastante heterogênea a oferta de instrução (por meio da qual dividiam espaços os colégios caros e baratos), seja porque o Estado Imperial somava suas forças com a da iniciativa particular para promover naqueles colégios pagos, a instrução das crianças em "extrema pobreza". Nestes casos, o poder público financiava o ingresso, a matrícula e a permanência daqueles alunos e alunas pobres (filhos de escravos libertos, de pescadores, vendedores ambulantes, pequenos comerciantes) nos colégios privados da Corte Imperial, com a promoção dos processos de subvenção. As mensalidades daqueles meninos e meninas eram pagas pelo Tesouro Nacional. Com efeito, diante do objetivo de somar forças e esforços no intuito de fazer funcionar o projeto de escolarização, o público e o privado misturavam-se, confundiam-se, imbricavam-se (LIMEIRA, 2010).

Se o Estado não fosse o único responsável pela instrução primária, a despesa com o ensino não seria de exclusividade pública. Em vista de dividir os gastos com a instrução primária, o discurso de direito de escolha se ancora em outros princípios e cria outros efeitos. O texto de Ana Luiza da Costa $(2009$, p.9) analisa o discurso proferido por Leôncio de Carvalho, apresentando todo o seu "ar progressista", "liberal" e preocupado com a formação do cidadão. No entanto, o texto pode evidenciar uma contradição, já que anuncia a preocupação com a "máxima economia para os cofres públicos", o que pode indicar a adoção ao ensino livre não só pelo respeito aos direitos individuais, mas também, como medida econômica e como ânimo às iniciativas privadas. Os indícios anotados apontam que a liberdade do ensino e a permissão do ensino particular podem ter ajudado a reduzir a responsabilidade da esfera pública com a instrução, na medida em que a proliferação de escolas particulares e a aceitação da instrução doméstica dividiam os custos (ALMEIDA, 2012, p.185).

No entanto, mesmo considerando que a liberdade do ensino, o fomento à iniciativa privada, as subvenções públicas aos estabelecimentos particulares de ensino tivessem sido apresentados como medidas de caráter econômico que possibilitaria a expansão da instrução primária, o Estado Imperial não as promoveu sem restrições. Muito pelo contrário. Outro princípio que se somava ao da liberdade ou incentivo à iniciativa particular era o da fiscalização e controle destas experiências.

Era preciso definir uma estratégia de fiscalização para estabelecimentos e agentes da educação. Caso o Estado não tivesse controle sobre como procedia o ensino nas escolas e na instrução particular, sobre os professores, pais ou tutores encarregados da prática do ensino, sobre os inspetores e todos os procedimentos pedagógicos, a liberdade do ensino tornar-se-ia um entrave para a fiscalização do cumprimento do ensino compulsório. E essa era uma preocupação encontrada nos relatórios oficiais de diversas províncias do país.

Mesmo aquelas autoridades que se declaravam favoráveis às subvenções, não hesitavam em declarar que aqueles processos eram de medidas paliativas, de "experiências", cujo intuito era avaliar uma potencial demanda, ou a real necessidade em estabelecer, no local, uma escola pública. Isso porque as escolas particulares não alcançariam o nível de qualidade ou confiança que atestavam as instituições mantidas pelo Estado Imperial. O fato de a iniciativa particular "gerenciar" a instrução, apesar de imbricada ao poder público pelo auxílio financeiro, parecia provocar relativa ameaça ao Estado Imperial. Ou seja, os espaços privados de escolarização estavam, de alguma maneira, menos sujeitos à vigilância e fiscalização do governo que as escolas públicas, e, por isso, suscetíveis a burlar as normas em vigor, promovendo uma diversidade de práticas educacionais, contratando profissionais sem habilitação, adotando métodos, saberes e compêndios sem autorização, etc. (LIMEIRA, 2010). 
Caso o Estado não controlasse o que era ensinado nas escolas, a formação dos professores, a frequência e matrícula das crianças em idade escolar, ou não controlasse a condução do ensino particular e/ou domiciliar, a obrigatoriedade, neste segmento, consistiria em desafio e talvez, em alguns casos uma "letra morta". Nesse sentido, fiscalizar o ensino fora da escola consistia numa importante medida a ser tomada.

Em anos posteriores ao Oitocentos, na República, ampliaram-se os incentivos para o ensino particular, mas ao mesmo tempo, não se abriu mão dos meios para se controlar o ensino, como evidenciavam os discursos sobre formação, as estatísticas (recenseamento escolar), e principalmente, a partir das exigências do espaço escolar - relacionado com a ideia de espaço disciplinar (ALMEIDA, 2012, p.184).

Como se pode observar, seja na defesa pelo processo civilizador, como na defesa pelos direitos individuais e civis, existem muitas justificativas com pretensão de sustentar princípios como a obrigatoriedade e a liberdade de ensino. A conjectura levantada é que ela ainda foi pensada enquanto uma estratégia de controle da população e a liberdade do ensino, enquanto uma política econômica de governo (ALMEIDA, 2012, p.181). No que se refere a essas políticas, alguns dirigentes afirmaram que a adoção da liberdade do ensino particular pode ter prejudicado a fiscalização da instrução primária e o controle da população, apesar da tentativa de se impor normas, métodos, saberes e condições para a prática do ensino por particulares.

Embora tenha aparecido ao lado da obrigação escolar no decreto de Leôncio de Carvalho e em outras legislações da Corte e em Minas Gerais, a liberdade de ensino dificultaria o cumprimento da obrigatoriedade, de acordo com alguns agentes do executivo. Se a escola pública, mais que um espaço educativo, era pensado como um espaço de vigilância e formação de condutas, nela o conteúdo das disciplinas, a formação e o comportamento dos professores e alunos, as regras e a moral necessária nesse processo de continuação da ordem e progresso da nação deveriam ser fiscalizados. Desta forma, ao permitir e estimular que a escolarização fosse compartilhada por outras vias, a fiscalização tornar-se-ia obstaculizada pelo novo perímetro de controle que se abria com as experiências de escolarização nos domicílios e nas escolas particulares, já que o acesso a esses estabelecimentos era mais limitado e impreciso, conforme relataram os relatórios da Província mineira.

Não se trata, entretanto, de uma rede de incompatibilidades. A ideia é que se existissem meios adequados de efetivá-las, elas poderiam e deveriam atuar como complementos no processo de expansão do ensino, já que ambas fazem parte das medidas utilizadas como ferramentas voltadas para a formação do povo. Porém, se não houver condições favoráveis para a eficácia dessas medidas, a liberdade do ensino poderia interferir no controle do Estado sobre a instrução da população.

Se a intenção da obrigatoriedade foi garantir a instrução elementar para a população enquanto condição e propósito de se alcançar o ideal de nação civilizada, torna-se complexo conciliar em outra medida que diminuísse as chances de êxito. A economia nos cofres públicos, por exemplo, não faz sentido se aplicada sobre a medida apontada pelo próprio governo como "o remédio para os males sociais". Segundo Alessandra Schueler Martinez, o consenso entre os dirigentes do Estado Imperial era de que "toda despesa feita com a instrução popular seria, na verdade, 'uma economia', porque diminuiria o número de indigentes, enfermos e criminosos, facilitando a poupança com os gastos de hospitais, asilos e cadeias" (MARTINEZ, 1999, p.12).

Baseando na hipótese de controle da população e governo dos outros, era preciso assegurar que a obrigatoriedade $\mathrm{e}$ todos os demais regulamentos que regiam $\mathrm{o}$ 
funcionamento das escolas públicas e privadas em todo país fossem cumpridos. A liberdade foi uma bandeira defendida, mas não sem controle.

A escola, a fiscalização, a formação dos professores eram expressões da presença de uma cultura que se materializou na modernidade e que enredava a cultura escolar em sua oposição ao mundo rural e a edificação de um mundo urbano com uma nova ordem de saberes fundamentado em uma nova linguagem: a escrita. Nessa direção, seja nos países europeus, nos demais países da América do Sul, como no Brasil, houve inicialmente um papel central da família e principalmente das congregações religiosas, "mas o advento do liberalismo e da formação dos Estados Nacionais" traria para o Estado o papel de direção desses estabelecimentos de ensino (GATTI \& INÁCIO FILHO, 2009, p.4).

Sob os aspectos relacionados à inspeção do ensino particular, o médico Pires de Almeida argumentava que "o poder central [...] não consentirá jamais, sob pena de suicidar-se e de conduzir a nação à anarquia, que a instrução fique sem direção central nem controle, que seja livre na acepção da palavra", e que a necessária fiscalização, consistia numa medida cuja justificativa buscou evitar o que chamava de "desordens":

Quando decretar a liberdade absoluta do ensino ver-se-ão surgir imediatamente estabelecimentos de educação onde reinarão desordens ainda mais graves que aquelas das quais lamentamos, às vezes, hoje. À regra, à uniformidade veremos suceder a especulação, abrindo internatos e externatos como existiam na Inglaterra [...] onde crianças morriam na miséria, onde matavam-se alma e corpo (ALMEIDA, 2000, p. 94).

Neste sentido, é preciso considerar que a liberdade do ensino mesmo tendo sido uma política educacional adotada no Brasil, não minimizou a tentativa de controle do Estado sobre a instrução. Toda normalização e legalização do ensino foi "proclamada" em forma de texto e se fez aplicar aos distintos espaços, fossem eles públicos, privados, escolares ou domésticos. No processo, legitimavam-se estas práticas ao passo que as submetiam à autoridade legal e jurídica dos dirigentes do país, num esforço de tornar as escolas espaços privilegiados para a transmissão de determinados saberes e constituição de uma ordem.

Em 1872, o Inspetor Geral da Instrução Pública encaminhou ofício a todos os delegados do Rio de Janeiro, requerendo dos mesmos as seguintes informações: lista dos nomes dos colégios particulares da localidade, frequência dos alunos de cada um desses estabelecimentos em 1871, com relação de idades, matérias ensinadas, compêndios usados, uma pequena observação em que constasse o conceito do delegado sobre cada um dos estabelecimentos, uma relação nominal dos alunos que participaram dos exames públicos do ensino primário, e uma declaração das demandas e necessidades do ensino público e particular da freguesia (ARQUIVO GERAL DA CIDADE DO RIO DE JANEIRO).

As respostas podem ser analisadas a partir da leitura dos Relatórios dos Ministros do Império. No ano de 1873, por exemplo, há uma lista com as observações daquelas autoridades relatadas em ofícios. Responsável pela freguesia da Glória, o delegado Candido Pereira Monteiro escreveu, entre outras coisas, que é "muito bom" o conceito dos colégios particulares da localidade, e que nunca recebeu "queixa" ou "denúncia" contra nenhum deles.

São registros que dão a ver a perspectiva daquelas autoridades acerca da qualidade do ensino público e particular e os resultados das fiscalizações (ditas sempre como realizadas). Apareciam naqueles documentos questões relativas às condições de salubridade e higiene dos ambientes, números de meninos e meninas matriculados, 
matérias ensinadas, métodos adotados etc. Há ainda outros que, expondo aspectos da vida íntima daqueles sujeitos envolvidos com a educação, tornavam-na pública. $O$ fato que exemplifica a observação refere-se ao ano de 1867, e trata-se de uma ordem de suspensão do título de habilitação para o magistério de um professor adjunto (Appriano Henrique Almeida) e de uma professora particular (Amélia Beltrão), decretada pelo Inspetor Geral e que fora encaminhada ao delegado. A razão? Os dois mantinham relação amorosa secreta e proibida há muito tempo e "sem consentimento do seu marido". A resposta do delegado, enviada no dia seguinte ao recebimento da ordem do Inspetor, comunicava que os professores fugiram juntos.

Formas distintas e dispersas de ensino e aprendizagem coexistiram por muito tempo entre os séculos XIX e XX, e, concomitantemente, vão se fortalecendo o controle progressivo do Estado sobre a educação formal e as iniciativas para organizar o sistema de instrução primária. A presença do Estado aparece representada em muitas medidas que observam nos regulamentos, leis, decretos, normatizações. Tudo representava o "olho" do Estado, a vigilância do mesmo sobre o cumprimento dos mecanismos determinados, como seu monitoramento acerca da instituição das técnicas e normas consideradas ideais para o projeto de nação, a formação de uma sociedade normalizada.

Algumas medidas foram desenvolvidas no sentido de unificar o sistema, entre elas: adoção de métodos, definição de conteúdos, autorização ou proibição de livros, criação de normas de funcionamento, seleção oficial dos profissionais, sistema de fiscalização, modelo de formação do magistério, regras de abertura para colégios particulares. Todas estas, e as demais medidas, buscavam tornar homogêneo um sistema que se caracterizava pela diversidade, já que a aproximação dos indivíduos com a cultura letrada se dava a partir de iniciativas tradicionais e muito diversificadas: família, igreja, preceptores, mestres particulares, corporações profissionais, escolas (públicas e particulares), associações filantrópicas etc. Desta feita, é possível observar que experiências escolares da iniciativa pública e particular eram paulatinamente inseridas nos projetos de controle do Estado Imperial em relação à instrução.

Se o interesse do governo era controlar a instrução da população, como se tem entendido nos documentos, como pensar o instituto da liberdade do ensino e as dificuldades de controle provocadas? Uma hipótese é imaginar que esta medida permitia que o ensino obrigatório fosse aplicado em escolas particulares e também dentro dos próprios lares. Ou seja, quem garantiria que os métodos e os saberes impostos pelo Estado estavam sendo seguidos, ainda que existam trabalhos que mostram que existia uma fiscalização nas escolas particulares? Se, nas próprias escolas do governo havia denúncias de burlas de pais, professores e inspetores, como pensar tais práticas na particular?

\section{Considerações finais}

O debate acerca destes princípios como obrigatoriedade ou liberdade de ensino é uma questão ainda aberta em nosso tempo. A Emenda Constitucional n.59 de 11 de novembro de 2009, que traz alterações para a Constituição Federal de 1988 no seu art.208, determina que a "educação básica obrigatória e gratuita dos 4 (quatro) aos 17 (dezessete) anos de idade, assegurada inclusive sua oferta gratuita para todos os que a ela não tiveram acesso na idade própria" (2009) ${ }^{13}$ passa a ser prioridade dentre as estratégias de universalização da educação, pois de acordo com essa mesma lei o "acesso ao ensino obrigatório e gratuito é direito público subjetivo" (Constituição da República Federativa do Brasil, 1988, Art. 208, parágrafo primeiro). A Emenda estabelece o prazo até 2016 para 
sua progressiva implementação nas redes federais, estaduais e municipais. Até lá, todos os sistemas de ensino têm de se adequar, conforme parâmetros a serem estipulados pelo Plano Nacional de Educação. Com essa mudança, os brasileiros deverão cumprir 14 anos de ensino gratuito e obrigatório. No entanto, acreditamos que essa seja uma discussão que ganhará espaço por muitos anos.

Para não concluir, haja vista as inúmeras lacunas que este tipo de investigação dá a ver, nos interessa pensar acerca da própria função dos estudos que se inscrevem no campo da História da Educação. As histórias que vasculhamos nos documentos e que foram trazidas à cena em nossas reflexões como fragmentos estão inalcançáveis em seu passado. O que está lá não nos é possível mudar. Em nada vale tais discussões, portanto. Destarte, consideramos que pensar historicamente o mundo é perceber coisas, saberes, normas, instituições como projetos, não naturais, eternos ou imutáveis.

Partilhamos com Foucault que a maneira mais interessante de se posicionar na realidade que nos é imposta e da qual fazemos parte, resistindo, legitimando, forjando é tomar partido da crítica permanente. É, enfim, estar historicamente na vida. Como Michel Foucault sugere em seus investimentos reflexivos, nós "devemos ter respeito e violar (estranhar, desconfiar, desconstruir?) este presente. E sua história nos propõe formas de ultrapassagem" (FOUCAULT, 2008, p.348).

\section{Referências:}

ALMANAK LAEMMERT. Rio de Janeiro, 1844-1889.

ALMEIDA, Cintia Borges. Entre a tyramnya cruel $e$ a pedra fundamental: a obrigatoriedade do ensino primário como uma técnica de governo em Minas Gerais. Rio de Janeiro: UERJ, Dissertação (Mestrado em Educação). Programa de Pós Graduação em Educação, Universidade do Estado do Rio de Janeiro, 2012.

ALMEIDA, José Ricardo Pires de. Instrução Pública no Brasil (1500-1889). Trad. Antônio Chizotti. 2. ed. São Paulo: EDUC, 2000.

BARBOSA, Rui. Reforma do ensino primário e várias instituições complementares da instrução pública. In Obras Completas de Rui Barbosa, v.X, tomo I ao IV. Rio de Janeiro: Ministério da Educação e Saúde, 1947.

BARROSO, José Liberato. A instrucção pública no Brasil. Organizado por Elomar Tambara e Eduardo Arriada. Pelotas: Seiva; 2005.

BASTOS, TAVARES. A Província. FAC-SIMILAR,1996.

BORGES, Vera Lúcia Abrão. As medidas de reforma acerca da Instrução Pública primária em MG:1892 a 1898. Tópico da tese de doutorado, 1998.

CORREIO DE MINAS. Juiz de Fora, 13 ago./1907.

COSTA, Ana Luiza Jesus da. As escolas noturnas da Corte: Estado imperial, sociedade civil e educação do povo(1870-1889). Educação e Sociedade, 2009.

FALAS DIRIGIDAS À ASSEMBLEIA LEGISLATIVA PROVINCIAL DE MINAS GERAIS PELOS PRESIDENTES DA PROVÍNCIA. 1837-1888. Disponível em: $<$ http://www.crl.edu/catalog/index.htm>. Acesso em: outubro de 2012. 
FALAS DIRIGIDAS À ASSEMBLEIA LEGISLATIVA ESTADUAL DE MINAS GERAIS PELOS PRESIDENTES DO ESTADO. 1889-1915. Disponível em: <http://www.crl.edu/brazil/provincial/minas_gerais>. Acesso em: fevereiro de 2011.

FALAS DIRIGIDAS À ASSEMBLEIA LEGISLATIVA PROVINCIAL DO RIO DE JANEIRO PELOS PRESIDENTES DA PROVÍNCIA. 1854-1888. Disponível em: < http://brazil.crl.edu/bsd/bsd/hartness/predpub.html>. Acesso em: outubro de 2012.

FOUCAULT, Michel. O que são as luzes? In.: Ditos\&Escritos II (Arqueologia das Ciências e História dos Sistemas de Pensamento). Trad. Elisa Monteiro. 2.ed. Rio de Janeiro: Forense Universitária, 2008, p. 335-351.

INÁCIO FILHO, G. ; GATTI JR, Décio. Aspectos da Formação Cívica e Patriótica dos Discentes do Ginásio Mineiro de Uberlândia, Minas Gerais (1920-1970). In: V Congresso de Pesquisa e Ensino em História da Educação em Minas Gerais, 2009, p. 1-16.

GIL, Natalia. Questão de interpretação: as disputas em torno das estatísticas de educação. III Congresso Brasileiro de História da Educação: SBHE, 2004.

Aparato burocrático e os números do ensino: uma abordagem histórica. Cadernos de Pesquisa, maio/ago. 2008, v. 38, n. 134, p. 479-502.

GONDRA, José; SCHUELER, Alessandra. Educação, poder e sociedade no Império brasileiro. São Paulo: Cortez, 2008.

GOULEMOT, Jean Marie. 1991. As práticas literárias ou a publicidade do privado. In.:

LIMA, Alexandra da Silva. Ensino e mercado editorial de livros didáticos de História do

Brasil - Rio de Janeiro (1870-1924). Niterói: UFF, Dissertação (Mestrado em História). Programa de Pós Graduação em História, Universidade Federal Fluminense, 2008.

JORNAL O APÓSTOLO. Rio de Janeiro, 1866-1894.

LIMEIRA, Aline de Morais. O comércio da instrução no século XIX: Colégios particulares, propagandas e subvenções públicas. Rio de Janeiro: UERJ, Dissertação (Mestrado em Educação). Programa de Pós Graduação em Educação, Universidade do Estado do Rio de Janeiro, 2010.

MARTINEZ, Alessandra Frota. Crianças e escolas na passagem do Império para a República. Revista Brasileira de História, São Paulo, v.19, n.37, p.59-84, 1999.

Educar e instruir: a instrução popular na Corte imperial. Dissertação de Mestrado em História, Niterói: UFF, 1999.

MINAS GERAIS. Lei n. 13 de 28 de março de 1835. Livro da Lei Mineira. APM.

MINAS GERAIS. Regulamento n. 3 da Lei n. 13 de 28 de março de 1835. Livro da Lei Mineira. APM.

MOURÃO, Paulo Kruger Corrêa. O ensino em Minas Gerais no tempo do Império. Belo Horizonte, 1959.

OLIVEIRA, Antonio Almeida de. O ensino público. 2.ed. Brasília: Senado Federal, Conselho Editorial, 2003.

WERLE, F. O. C. Políticas de instrução pública no século XIX como eco de experiências internacionais. Educação, Porto Alegre, maio/ago. 2008, v. 31, n. 2, p. 173-181.

Revista HISTEDBR On-line, Campinas, $n^{\circ}$ 52, p. 90-106, set2013 - ISSN: 1676-2584 105 


\section{Notas}

${ }^{1}$ Universidade do Estado do Rio de Janeiro - Núcleo de Ensino e Pesquisa em História da Educação (NEPHE-UERJ) Fundação Biblioteca Nacional Email: aline.de.morais@oi.com.br

${ }^{2}$ Universidade do Estado do Rio de Janeiro - UERJ Núcleo de Ensino e Pesquisa em História da Educação (NEPHE-UERJ) Email: cintiaborgesalmeida@yahoo.com.br

${ }^{3}$ Ver: ALMEIDA, Cíntia; NEVES, Dimas; GONDRA, José. Ensino obrigatório: "Prudente é esperar-se do tempo o preciso remédio". Porto Alegre: Revista de História da Educação - RHE, v.16, n.38, set./dez de 2012, p.126-148.

${ }^{4}$ Conferir MARTINEZ, 1999, p.17: Na Província do Rio de Janeiro, por lei de 1835, os "pretos africanos livres ou libertos" também eram impedidos de obter instrução nas escolas do governo. Ver MATTOS, Opus cit. p.261. Para a Corte, não encontramos a proibição legal aos libertos e africanos livres, porém, é significativo que, em 1878, o Ministro do Império Leôncio de Carvalho, ao criar cursos noturnos de adultos, tenha expressado literalmente que a matricula seria franqueada aos libertos, sinal de que talvez esta entrada fosse impossibilitada ou dificultada até então.

${ }^{5}$ Foi deputado provincial, deputado geral, ministro do Império (o ministro mais longevo no cargo em toda a monarquia), ministro da Agricultura, ministro da Fazenda (de 10 de março de 1888 a 7 de junho de 1889), conselheiro de Estado, presidente de província (Pará e São Paulo) e senador de 1877 a 1889. Defendeu a obrigatoriedade em seu Projeto de Lei, de 30 de Julho de 1874.

${ }^{6}$ Falla dirigida à Assembleia Legislativa Provincial de Minas Geraes na sessão ordinária do ano de 1840, pelo presidente da província, Bernardo Jacintho de Veiga.

${ }^{7}$ Relatório que á Assembleia Legislativa Provincial de Minas Geraes apresentou na abertura da sessão ordinária de 1856, o conselheiro Herculano Ferreira Penna, presidente da mesma província.

${ }^{8}$ Relatório do presidente Francisco Diogo Pereira de Vasconcellos, da Província de Minas Gerais, 1854.

9 Apesar da Escola Normal em Minas ter sido criada em 1835, somente em 05 de março de 1840 que ela iniciou suas atividades (MOURÃO, 1959, p.32). Mesmo assim, em 1842 ela foi fechada, voltando a ser reaberta somente em 1847, a partir do acordo com o art. $3^{\circ}$ da Lei de 08 de abril de 1846 (idem, idem, p.34). Até o ano de 1851 só constavam dados de 53 discípulos nos registros das Aulas Normais (ibidem, p.47), não tendo permanência de atividades, já que em 06 de maio de 1852 ela voltou a ser suspensa. Toda essa inconstância das aulas normais acabou gerando um problema para o Estado acerca da formação de seus professores. A solução encontrada foi os concursos e exames de habilitação. Os candidatos deveriam comparecer à Capital para realizar provas de habilitação de acordo com o que prescrevia o artigo 63 e o 43 do Regulamento n.28, que exigiam concursos por provas e exibição de documento a juízo: comprovação de idoneidade e moralidade atestado pela igreja juntamente com uma certidão de crença religiosa e certidão de maioridade.

${ }^{10}$ Para se abrir uma escola, em vários momentos do Império como da República, era preciso apenas de um comprovante de idoneidade e moralidade. Não se exigia a formação normal. Para que a escola permanecesse aberta as leis mineiras estabeleciam um número mínimo de matrículas e de frequência. Caso esse número não fosse cumprido, as escolas estavam sujeitas ao fechamento pelo Estado.

${ }^{11}$ Leôncio de Carvalho (Ministro do Império). Titular da Pasta do Império, à qual estava subordinada a Instrução Pública. Leôncio discorrerá sobre a obrigatoriedade, no entanto, adotando o ensino livre como indispensável para a expansão da escolarização, sendo o autor do Decreto-Lei de 19 de abril de 1879, que explicitou no artigo $1^{\circ}$ do referido documento que, "o ensino tornará inteiramente livre e obrigatório".

12 BARROSO, Liberato. A instrução pública no Brasil. Pelo Conselheiro José Liberato Barroso - 1867. Pelotas: Seiva. Série Filosofia e História da Educação, 2005.

${ }^{13}$ Disponível em < http://www.planalto.gov.br/ccivil_03/constituicao/emendas/emc/emc59.htm>. Acesso em: 06 abr.2012.

Recebido em outubro-2012

Aprovado em agosto-2013 